\title{
Combustion Characteristics of Gas Fuel From Basic Materials Arak Bali
}

\author{
I Gusti Ketut Sukadana ${ }^{1)}$ \\ ${ }^{1)}$ Mechanical Engineering Department of Udayana University, Badung-Bali
}

\begin{abstract}
Analyze the characteristics of gas fuel from arak Bali like shape and flame speed. Test characteristics such as methanol and ethanol content material gas from arak Bali, after it tested the gas fuel combustion characteristics of arak Bali such as the shape and speed of flame. Testing characteristics such as the content of methane and ethanol gas from arak Bali performed in the laboratory of Forensic, while testing the ignition characteristics of the shape and speed of fuel from evaporating arak Bali done using a helle-shaw cell combustion chamber model. Air mixture ratio variations with gas fuel from arak Bali is 24/1, 25/1, 26/1, 27/1, 28/1,29/1,30/1 and 31/1. The observed effect is the shape and speed of the premixed flame propagation in the helle-shaw cell combustion chamber model. The results of the study, the moisture content of the basic ingredients of gas fuel arak Bali consisting of 40\% methanol and 60\% ethanol. To gas fuel from arak Bali has AFR stoichiometry on 30/1. Getting closer to the AFR stoichiometry, flame color changes from reddish color faded to red, reddish blue, blue and bright blue last. Maximum speed of propagation of fire occurred in AFR stochiometry is $328.33 \mathrm{~cm} / \mathrm{sec}$.
\end{abstract}

Keywords: Characteristics, fuel gas, arak Bali, burning, helle-shaw cell

\section{Introduction}

The government of Indonesia in 2008 to make a policy on the management of national energy, about the use of ethanol, biodiesel and gasohol as an alternative energy in 2022. One source of alternative fuel in Bali is arak Bali. Arak Bali with quality above of $85 \%$ has an octane number about 108,6. Arak Bali are non-toxic and when used as an environmentally friendly fuel. Arak Bali fuel mixed with gasoline at a certain percentage can increase the octane number of gasoline. Increased octane rating will improve the quality of combustion, decreased residual gases of combustion and increased engine performance.

The use of arak Bali as an alternative energy, from 2006 has done research the use of arak Bali in liquid form as a fuel substitute for gasoline, with examining on the internal combustion engine carburetors and injection machines, with some testing variables such as rotation and compression ratio. Compared with gasoline, arak Bali fuel produces $\mathrm{CO}_{2}$ emissions is a larger than gasoline, lower $\mathrm{CO}$ emissions, higher $\mathrm{HC}$ emissions and higher $\mathrm{O}_{2}$. increased compression ratio to affects the increase of $\mathrm{CO}_{2}$, decrease of $\mathrm{CO}$ and $\mathrm{HC}$ and the smaller increase in gas $\mathrm{O}_{2}$, rotation engine is less steady, engine torque is decreas, engine power and engine torqy decrease at low rpm.

In this study using arak Bali fuel in gaseous form. To obtain the fuel gas from arak Bali, arak Bali requires heating processes. Perfect gas combustion is influenced by three things: the air fuel ratio, homogeneity of mixing and combustion temperatures. Comparison of fuel with air is less than perfect impact to perfection of combustion, which can be seen in the shape and velocity of the fire.

Research using gas fuel combustion has been carried out such as: Adi Winarta in 2007 a study the mixture ratio of air and natural gas fuel to form and velocity of a fire, the results showed that the stoichiometry of the combustion air is in comparison with the fuel gas is $8 / 1$ and the maximum flame propagation velocity is achieved in the mixture stoichiometry. Therefore we are interested in continuing research to determine the characteristics of the fuel gas content of arak Bali and its effect on combustion characteristics.

\section{Literature Review}

Nanda, Sukadana 2006, tested the mixture of arak Bali and gasoline by varying the fraction of the mixture to obtain physical properties closer on gasoline. And followed by Artayana, Sukadana on 2007 did test an addition of alcohol on gasoline to know the quality of the exhaust gas was tested on a motorcycle engine. This research produced, the greater percentage addition of alcohol causes the exhaust gases produced as hydrocarbon and oxygen is increased, the gasoline exhaust gas tends to be lower. The greater percentage of the engine rotation the exhaust gases produced is decreases.

Joni Artawan, Sukadana 2007, conducts research arak Bali as a substitute fuel motorcycle to the acceleration and fuel consumption. The results showed, at a compression ratio of 9.3/1 uses arak api can improve acceleration and can save fuel consumption, where are: in 1st gear at a speed of $0-20 \mathrm{~km} / \mathrm{h}$ acceleration is $2.835 \mathrm{~m} / \mathrm{dt}^{2}$ with a fuel consumption is $0.091 \mathrm{lt} / \mathrm{km}$, in $2 \mathrm{nd}$ gear at a speed of $20-40 \mathrm{~km} / \mathrm{h}$ acceleration is 1.190 
$\mathrm{m} / \mathrm{dt}^{2}$ with a fuel consumption is $0.102 \mathrm{lt} / \mathrm{km}$, in $3 \mathrm{rd}$ gear at a speed of $40-60 \mathrm{~km} / \mathrm{h}$ acceleration is $0.518 \mathrm{~m} / \mathrm{dt}^{2}$ with a fuel consumption is $0.117 \mathrm{lt} / \mathrm{km}$ and at the 4 th gear speed of $60-70 \mathrm{~km} / \mathrm{h}$ acceleration is $0.146 \mathrm{~m} / \mathrm{dt}^{2}$ with a fuel consumption is $0.183 \mathrm{lt} / \mathrm{km}$.

Ervan, Sukadana 2007, doing research on the procession of arak api as a substitute fuel motorcycle to the content of the flue gas, the results of research by varying the concentration of ethanol as a fuel will greatly affects the content of the exhaust gases. With a higher concentration of exhaust gas produced such as carbon dioxide is increases. The greater concentration of ethanol produced $\mathrm{CO}, \mathrm{HC}$ and $\mathrm{O}_{2}$ emissions is decreases.

Sukadana, Tenaya 2008, researchs the use of arak Bali four stroke engine as a fuel with a compression ratio variations. The results obtained fuel produces arak api to engine performance are better than gasoline, because it is able to work at a higher compression ratio so that the thermal efficiency in fuel use higher fire procession.

Sukadana, Bandem 2009 and 2010, conducting technical studies the performance of the continuous distillation and the use of wine as a fuel substitute for gasoline, by testing in conventional combustion engines in carburator, with several variable testing such as rotation variable, compression ratio variable to the engine performance such as emissions. Research results obtaineds, the higher temperature influence to the higher evaporation capacity wine products but inversely proportional to the product quality is getting lower. compared with gasoline, fuel arak produce high $\mathrm{CO}_{2}$ gas, low $\mathrm{CO}$, high $\mathrm{HC}$ and high $\mathrm{O}_{2}$. Increased compression ratio affect the increase in $\mathrm{CO}_{2}$, reduced $\mathrm{CO}, \mathrm{HC}$ emissions increase and the less gas $\mathrm{O}_{2}$.

Sukadana, Tenaya 2011, conduct technical studies continuous distilator column-type to the capacity and quality production. The results from this study that: capacity and quality of the wine production is influenced by many number of levels distillation. The greater level number influence to the lower of distillate production capacity, the higher quality of production and production efficiency are lower.

Sukadana, Tenaya 2013, doing research "Improving the quality of arak Bali production as an alternative fuel with Continuous distillation method". In this research conducted a variable number of levels distillation of one level, two levels and three levels. With each variable has a setting different tempratures. Showed that the more level of distillation in used can be produced quality wine production higher but lower production capacity.

Tenaya, Sukadana 2014, conducts research to increase production capacity of alternative fuels arak Bali used forced fluid flow method. From research conducted showed that more level of continuous distillation influence to temperature distribution pattern, lower evaporation, lower production rate and the quality of production is increases.

Sukadana 2015 has been carrying out research application the method of forced condensation-type crossflow on alternative fuel of arak Bali to quality and capacity production process. The bigger cooling fluid flow rate to results the greater cooling rate to affect the rate of condensation is greater, the rate of production is increases. But the greater cooling fluid flow rate to affects the quality of production is low. Arak Bali for testing as a fuel in the carburator type engine gived the result is to increased concentration of arak Bali affects the specific fuel consumption is increasing, decreasing torque and engine power.

One of the alternative fuel are beginning to get special attention is ethanol from arak Bali, a clear liquid with no color and unique aroma. Because it is non-toxic, widely used as a solvent in the pharmaceutical, food and beverage industry. Ethanol mixture with water gives a sweet taste, but at high concentrations will give you a burning sensation. With the molecular formula Ethanol is $\mathrm{C}_{2} \mathrm{H}_{5} \mathrm{OH}$, which is a group of chemical compounds containing hydroxyl compound-OH attached to a carbon atom (Wikipedia Indonesia, ensiklopedia bebas berbahasa Indonesia).

In addition to its clean combustion, as well as easily produced or by another name is a green fuel. Ethanol is a fuel that is produced by some plants includes palm trees. The main result of a number of plant species among others is juice, the juice obtained by tapping virgin coconut tree that has not bloomed. A virgin can be tapped for 10-30 days with the results obtained from 0.5 to 1 liters of juice per day. Nira can be easy to experience because it contains wild yeast fermentation. Fermentation will end one day later after the sugars in the juice runs out are converted so that the sap will contain alcohol. The sap will be distilled to produce wine. Nira used is derived from the sap of palm trees are often called by the Balinese coconut palm wine. In the destilation process of coconut sap will do some fractional distillation process to obtain varying levels of ethanol.

Fuel gas is ideal for internal combustion engines, because the gas phase is homogeneously mixed with air. Analysis of gas fuel is based on the analysis of volume measured at standard temperature and pressure $60{ }^{\circ} \mathrm{F}$, $30 \mathrm{inHg}$ or $15,56{ }^{\circ} \mathrm{C}, 1 \mathrm{~atm}$. Characteristics of gas fuel include: ignition temperature is the temperature at which the fuel gas can ignite by it self. Ignition temperature can not be calculated exactly the same as specific gravity is obtained from the experimental results. Inflammability limits. The temperature of the mixture of fuel and air can ignite in air at certain mixed conditions. The mixture boundary conditions known as flammability limit both the lowest and the highest. 
Good combustion is obtained the release of heat energy contained in the fuel, and suppres the amount of heat lost. Ideal Combustion is the burning of which produces only certain products. Ideal combustion is called stoichiometry, its combustion products of hydrocarbon fuels is $\mathrm{CO}_{2}, \mathrm{H}_{2} \mathrm{O}$, and $\mathrm{N}_{2}$. Combustion stoichiometry combustion says where all the atoms of the fuel and oxidizer react perfectly.

Combustion is classified into two: mechanics burning and natural burning. Premixed combustion is the process of burning fuel and air are mixed first mechanically and then burned. Combustion of this type can be seen in the process of burning gasoline motor, carbide welding, burning on a rocket. In the premixed combustion wave propagation combustion occurs is called the front frame. Combustion wave propagates toward the reactants, behind a wave of arson formed combustion products.

The air fuel ratio is the ratio between the air with the fuel into the combustion chamber. The mixture contains enough air for complete combustion process called stoichiometry. The mixture contains excess fuel called rich mixture, a mixture containing less fuel called lean mixture. In this study was engineered at the determination of fire propagation speed. Flame propagation velocity is defined as the velocity of the gas unburned perpendicular to the surface as a gas combustion wave moves toward the burning fields. Variables that affect the speed of combustion are: the ratio of oxidizer and fuel mixture, the molecular structure of the fuel, Additive, pressure and temperature of the mixture, the temperature of the fire and thermal diffusivity.

\section{Research Methods}

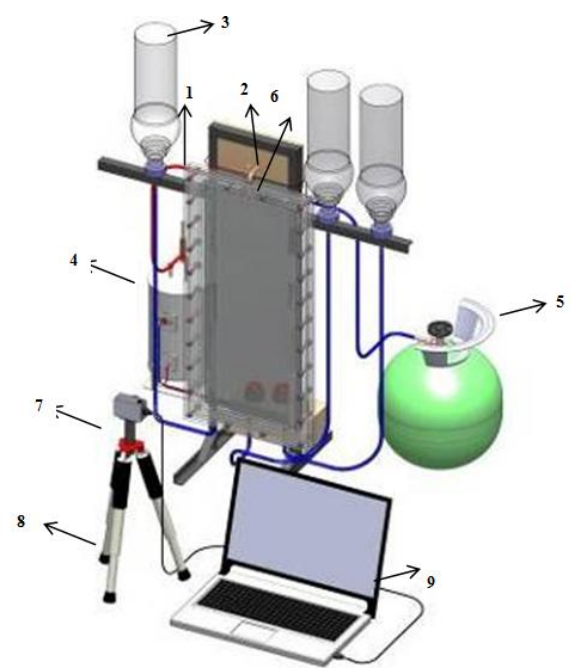

Figure1. Sekema research facility

Testing characteristics such as methane and ethanol content of the fuel gas from arak Bali conducted in Forensic laboratory. Testing characteristics of the shape and speed of ignition of the fuel gas from arak Bali performed by varying mixtures of air and fuel gas from arak Bali. Variables air fuel ratio is 24/1, 25/1, 26/1, $27 / 1,28 / 1,29 / 1,30 / 1$ and 31/1.

\section{Results And Discussion}

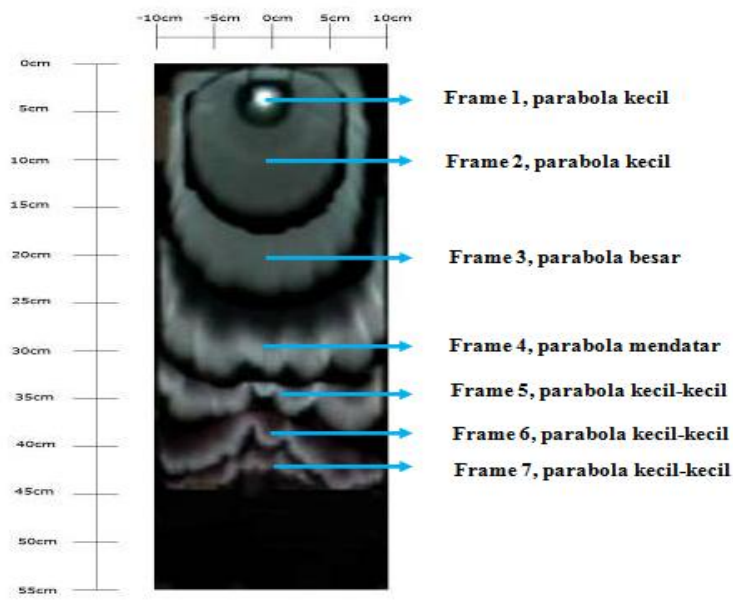

Figure2. The shape of flame propagation 
In generaly, the propagation of flame shape is parabolic, from a small satellite dish near lighters steadily developed into a large satellite dish, even further away from the lighter originally parabolic horizontal and eventually broke up into several small satellite dish, as shown at figure 2 .

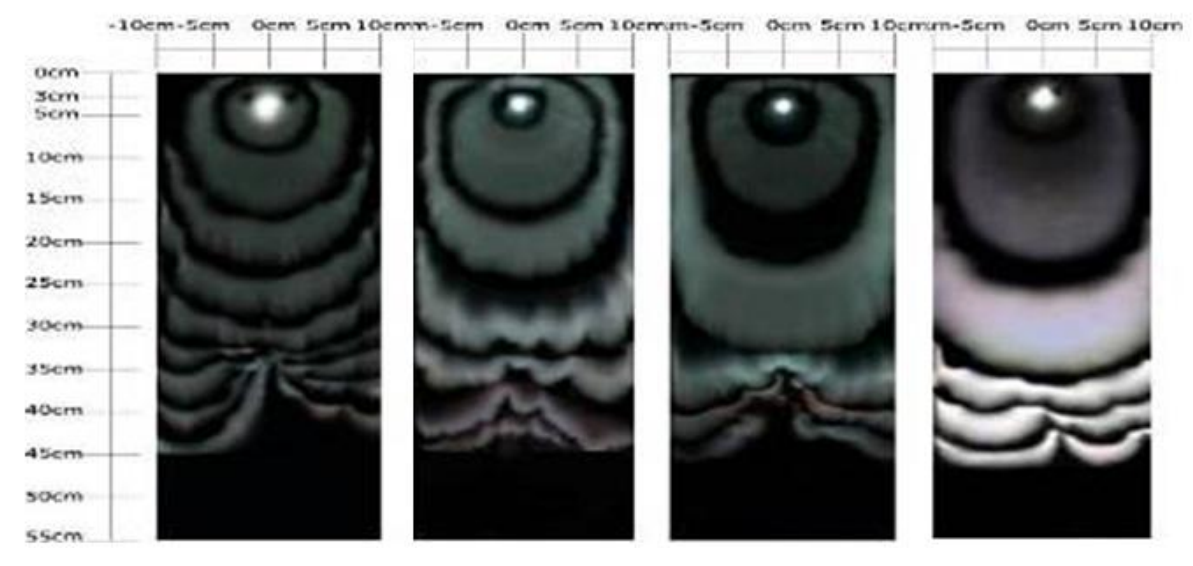

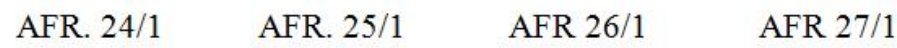

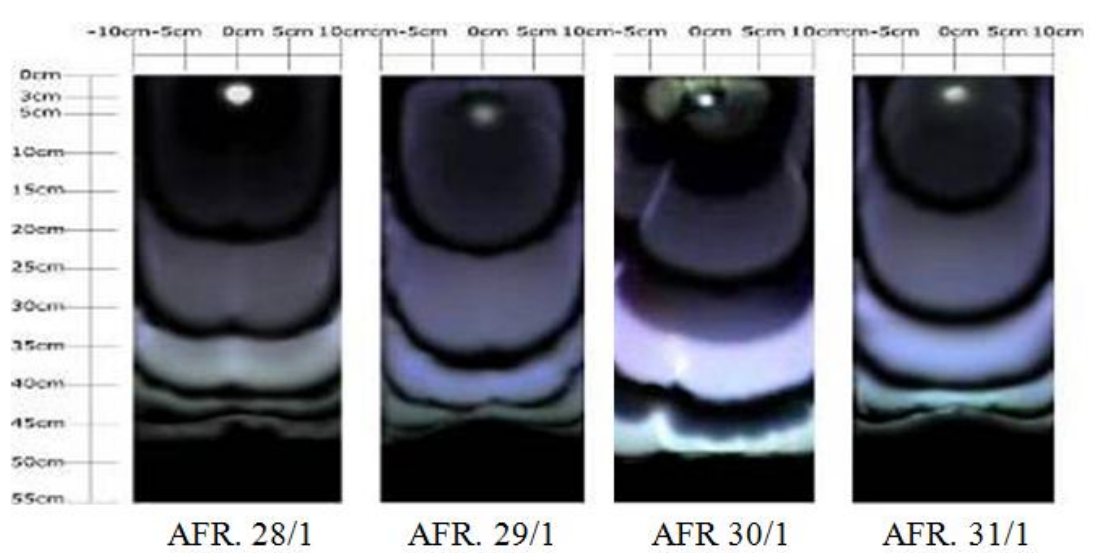

Figure3. The flow patterns propagation of fire with the lighting from above on a variation of AFR.

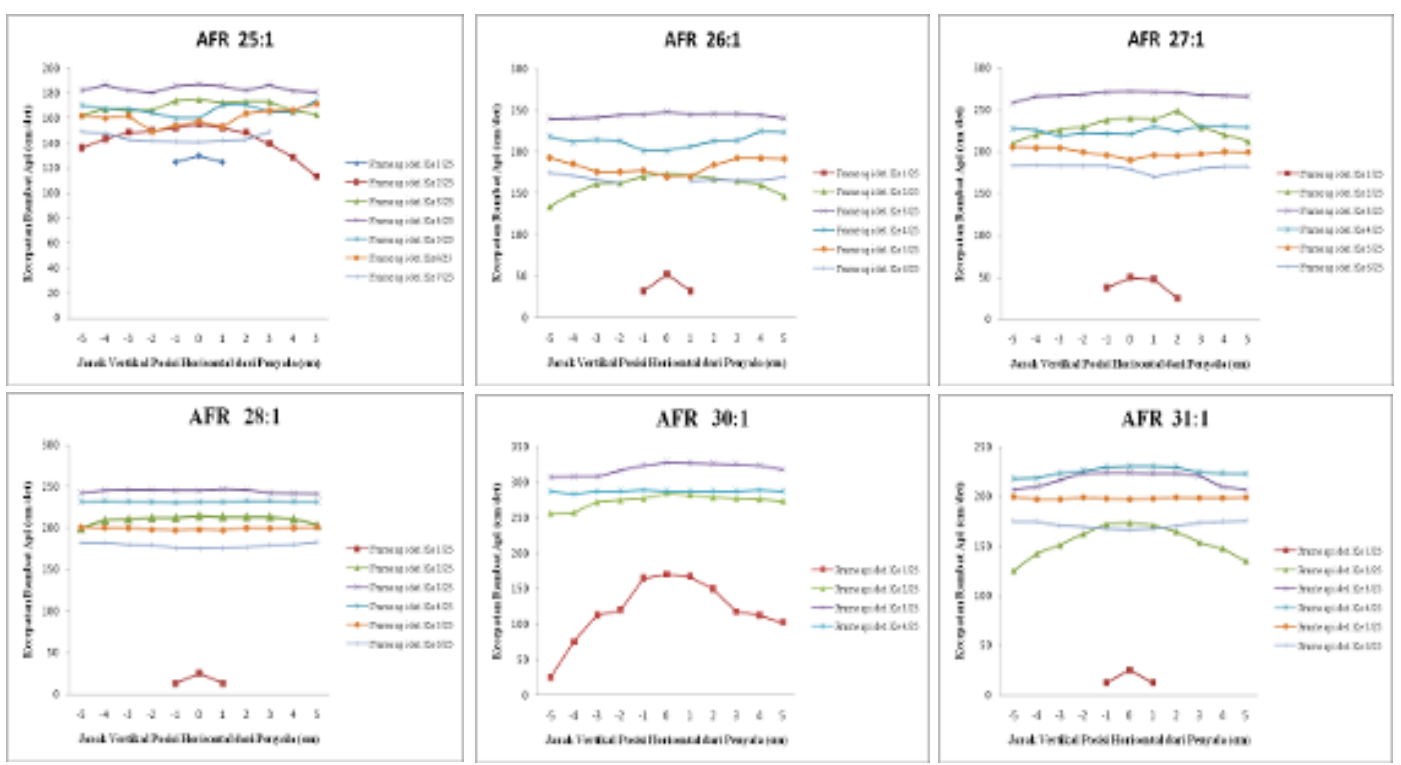

Figure4. Graph relationship vertical distance from the horizontal position with the ignition flame propagation velocity on every variation of AFR.

From the graph in Figure 4 above shows that the AFR greatly affect the speed of propagation of fire. This phenomenon occurs because with a ratio of air and fuel gas from arak Bali making process more complete 
combustion. Comparison of air and fuel is getting closer comparison stoichiometry raise fire velocity. In AFR $24 / 1,25 / 1,26 / 1,27 / 1,28 / 1,29 / 1,30 / 1$, and 31/1 maximum flame propagation velocity of each is $178.75 \mathrm{~cm} / \mathrm{sec}$, $187.50 \mathrm{~cm} / \mathrm{sec}, 248.33 \mathrm{~cm} / \mathrm{sec}, 271.67 \mathrm{~cm} / \mathrm{sec}, 246.67 \mathrm{~cm} / \mathrm{sec}, 268.33 \mathrm{~cm} / \mathrm{sec}, 328.33 \mathrm{~cm} / \mathrm{sec}$, and 230.63 $\mathrm{cm} / \mathrm{sec}$. With the AFR stoichiometry is on $30 / 1$ will generate the maximum flame propagation velocity, where the flame propagation velocity of $328.33 \mathrm{~cm} / \mathrm{sec}$.

\section{Conclusions}

Based on the results of research and discussion that has been done, it can be concluded as follows: the gas content of the basic ingredients of arak Bali consists of $40 \%$ methanol and 60\% ethanol. For gas fuel from arak Bali has AFR stoichiometry occur at 30/1. Getting closer to the AFR stoichiometry the fire changed color from reddish color faded to red, reddish blue, blue, and bright blue last. Maximum speed of propagation of fire occurred in AFR stochiometry is $328.33 \mathrm{~cm} / \mathrm{sec}$.

\section{Acknowledgements}

The author thanks to the Ministry of Research Technology and Higher Education of the Republic of Indonesia and LPPM University of Udayana for supporting this research and paper through The Grants at 2016 2017.

\section{Journals/Papers}

\section{Daftar Pustaka}

[1] Sukadana 2009, "Pengaruh rasio kompresi terhadap unjuk kerja mesin empat langkah menggunakan arak bali sebagai bahan bakar", Jurnal Ilmiah Teknik Mesin (CAKRAM), UNUD. ISSN: 1979-2468, April 2009, hal 26-32, Vol. 3 No. 1.

[2] Sukadana 2009, "Kajian Teknis Destilator Tipe Kontinu Penghasil Bahan Bakar Alternatif dari Bahan Dasar Arak Bali", Jurnal Ilmiah Teknik Mesin (CAKRAM), UNUD. ISSN: 1979-2468, April 2009, hal 38-42, vol. 3 No. 1.

[3] Sukadana 2014, "Pengaruh Jumlah Tingkat Destilasi Kontinyu terhadap Kualitas dan Kapasitas Produksi Arak Bali sebagai Bahan Bakar Alternative”, Jurnal Energi dan Manufaktur, Th. 2014, hal. 211-216, ISSN: 2302-555, Volume 7, Nomor 2.

[4] Sukadana 2016, "Pengaruh Penggunaan Arak Bali Sebagai Bahan Bakar Pada Mesin Empat Langkah Dengan Rasio Kompresi Bervariasi", Flywheel Jurnal Teknik Mesin Untirta, Volume II Nomor 1, April 2016.

[5] Sukadana 2016, "Ethanol Concentration Variations on Arak Bali influence to Torque, Power and Spesific Fuel Consumption of Engine ", The International Journal Of Engineering And Science (IJES), Volume || 5 || Issue || 8 || Pages || PP -35-39 || 2016 || ISSN (e): 2319.1813 ISSN (p): 2319. 1805

\section{Chapters in Books}

[6] Sukadana, 2009, 2010, "Kajian teknis destilator tipe continu penghasil bahan bakar alternatif berbahan dasar arak Bali", Laporan Penelitian, Universitas Udayana.

[7] Sukadana, 2011, "Kajian teknis pemanfaatan arak Bali sebagai bahan bakar alternatif mesin pembakaran tipe injeksi", Laporan Penelitian, Universitas Udayana.

[8] Sukadana, 2011, "Kajian teknis distilator kolom bertingkat tipe kontinu terhadap kapasitas dan kualitas produksi arak Bali", Laporan Penelitian, Universitas Udayana.

[9] Sukadana, 2013, "Peningkatan kualitas produksi arak Bali sebagai bahan bakar alternative dengan metode distilasi Kontinyu bertingkat", Laporan Penelitian, Universitas Udayana.

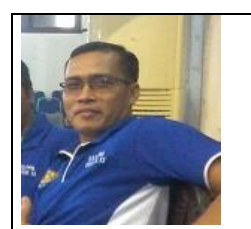

I Gusti Ketut Sukadana. Graduated (S1) at Mechanical Engineering Department of Udayana University in 1995, research area is the design of gas turbine blades in aircraft-engine Boeing 737-400. Education Masters (S2) at Mechanical Engineering Institute of Technology Sepuluh November in Surabaya at 2003, with the area of research on Natural Heat Transfer Phenomena. 